A QUESTION OF BALANCE 



\section{A Question of Balance}

Charles Seeger's Philosophy of Music

TAYLOR AITKEN GREER 
This book is a print-on-demand volume. It is manufactured using toner in place of ink. Type and images may be less sharp than the same material seen in traditionally printed University of California Press editions.

University of California Press

Berkeley and Los Angeles, California

University of California Press, Ltd.

London, England

(c) 1998 by

The Regents of the University of California

Library of Congress Cataloging-in-Publication Data

Greer, Taylor Aitken, 1955-

A question of balance : Charles Seeger's philosophy of music / Taylor Aitken Greer.

p. $\mathrm{cm}$.

Includes bibliographical references (p. ooo) and index. ISBN 978-0-520-21152-o (alk. paper)

1. Seeger, Charles, 1886-1979-Criticism and interpretation. 2. Music-Philosophy and aesthetics.

3. Musicology-United States-History-2oth century. I. Title.

\section{ML423.S498G74 $199^{8}$}

$781^{\prime} .092-\mathrm{dc} 21$

Printed in the United States of America

The paper used in this publication meets the minimum requirements of ANSL/NISO Z39.48-1992 (R 1997) (Permanence of Paper). 
To Cecilia, François, and Emile 
